\title{
Physicians and statisticians: two ways of creating demographic health statistics in Spain, 1841-1936
}

\author{
ESTEBAN RODRÍGUEZ-OCAÑA* \\ and JOSEP BERNABEU-MESTRE $\dagger$
}

\section{THE CREATION OF MODERN DEMOGRAPHIC STATISTICS}

The existence of a specialized administrative organization depends on the political, economic, and social development of a country, and is indispensable for the availability of modern statistics. As more than one author has pointed out, quantitative assessments of its population reflect a government's capacity to rule. ${ }^{1}$ The first Spanish attempts to obtain such quantitative knowledge are found in the so-called Relaciones ordered by Philip II in the second half of the sixteenth century; they described both European and American territories of the Crown. ${ }^{2}$ These early attempts, however, lacked continuity.

National censuses, with uneven periodicity, emerged under the eighteenth-century Bourbon monarchy which was particularly concerned to promote population growth. During the second half of that century, applying the principles of enlightened despotism to public health (sometimes called 'medical police'), the Spanish kingdom started to monitor burials. New health standards dictated that the site of burials be changed from chapels and adjacent churchyards to out-of-town (rural) cemeteries; the change reflected concern about the epidemics of malaria and yellow fever that haunted late-eighteenth-century Spain. ${ }^{3}$ The recording of burials, then, turned from an ecclesiastical procedure into a civic responsibility. The first modern nosological tables (lists of deaths by

\footnotetext{
* Department of Pathology and History of Science, University of Granada.

$\dagger$ Department of Public Health, University of Alacant.
} 
causes), drawn up by Dr Francisco Salvá y Campillo, recorded deaths in the city of Barcelona from 1787 to 1796.

Political instability in the early nineteenth century (war against France, the despotic rule of Ferdinand VII, the civil wars following his death) impeded the collection of demographic statistics. ${ }^{4}$ There were nonetheless numerous decrees and circulars whose object was to establish a civil register of births, marriages, and deaths with an indication of cause of death. ${ }^{5} \mathrm{~A}$ circular of 1837 assigned to priests the duty of including a cause of death in their parish records, while it was stipulated that a physician's certificate stating the cause of death was needed before burial in civil cemeteries. ${ }^{6}$ Through a decree of 1841 , a few cities, mainly provincial capitals, had obtained civil courts for the registration of births, marriages, and deaths, thereby replacing parish registers. Furthermore, in 1863 full control of the cemeteries was awarded to the municipalities. ${ }^{7}$ The nationwide extension of the Civil Registry (Registro Civil) as a local agency of the Department of Justice in charge of the collection of demographic data, however, took place only after 1871 .

The first steps towards the organization of modern statistics were taken with the creation of the Royal Commission for Statistics (Comisión Estadistica General del Reino) in 1856. By 1861 known as the General Board for Statistics (Junta General Estadistica del Reino), this organization was in charge of coordinating all statistics. In 1873 a new state agency, the Geographical and Statistical Institute (Instituto Geográfico y Estadistico), replaced the Board. ${ }^{8}$ These agencies collectively were responsible for the first Anuarios Estadísticos and the Movimientos de la Población de España (Anuario 1859, 1860/61, 1862/65, 1866/67; Movimiento ... en el Decenio de 1861 a 1870 and the Movimiento ... published in 1895).

The annual statistical reviews included, among other things, two chapters of demographic and public health interest. The first provides data on baptisms (distinguishing males and females and legitimate and illegitimate children), marriages, and deaths for each province and provincial capital. Deaths were also grouped by age, sex, and marital status of the deceased. From 1863 information was also provided about stillbirths and the deaths of infants before baptism. Births are tabulated by month, and deaths by month, cause of death, and occupation of the deceased. There was a separate section providing an inventory of deaths by age, making comparisons with other countries, and calculating the proportion of births, marriages, and deaths by total population and by area. Data on temperature, rainfall, and other geoclimatic variables were also given.

Even the early statistical boards recognized that these publications were riddled with problems. A lack of administrative resources and adequate 
TABLE 1

Dates of implementation of the International Classification of Diseases and Causes of Death in the Spanish Statistical Institute

\begin{tabular}{lcc}
\hline \hline Classification & & $\begin{array}{c}\text { Spanish } \\
\text { acceptance }\end{array}$ \\
\hline International Classification (Bertillon) & 1893 & 1900 \\
First revision & 1900 & 1901 \\
Second revision & 1909 & 1910 \\
Third revision $^{a}$ & 1920 & 1922 \\
Fourth revision $^{a}$ & 1929 & 1931 \\
Fifth revision & 1938 & 1941 \\
\hline \hline
\end{tabular}

${ }^{a}$ Produced by the Bureau of Health of the League of Nations.

personnel was the most important, but the lack of cooperation from priests - mainly because the task was at odds with their routines - added to the resulting ' great imperfections' of the early summaries. ${ }^{9}$ Citizens and local authorities, particularly when fearing underlying bureaucratic motives such as taxation, were frequently uncooperative, even hostile. ${ }^{10}$

Nationwide vital registration began on 1 January 1871, following the Royal Order of 17 June 1870 and a Royal Decree of 13 December 1870. Even so, the initiative was slow to take hold. By 1873 only 36 provinces (out of 49) were capable of providing the Statistical Institute with data for 1871 and 1872 . Even as late as 1887 many marriages and births, although registered in parish records, were still not on the civil registers. Mortality data were considered far more accurate, due to the longer secular control of the graveyards. ${ }^{11}$

Starting with data from 1900, in 1902 the Statistical Institute published annual series of demographic statistics, marking a major advance in Spain's modernization. ${ }^{12}$ In 1899 the Institute adopted the standard International Classification of Diseases and Causes of Death produced by the International Statistical Institute (ISI) and the abbreviated Bertillon terminology, and thereafter followed successive revisions closely. (See Table 1.)

\section{CAUSES OF DEATH AND HEALTH STATISTICS}

Compilation of the causes of death encouraged medical assessment of the health status of the population, forging one of the strongest bases for the development of public health over the course of the nineteenth century. Similarly, the quantitative approach was a cornerstone of the social 
medicine movement during the first third of the twentieth century. But, judging from the Spanish example, the medical perspective occupied an ambiguous position in the process of establishing a state-run demographic statistical agency. Medical interests encouraged refinements and improvements in the collection of causes of death even while leading doctors, eager to champion the cause of improved demographic statistics, in the end fiercely opposed the recommendations. Such concerns stimulated the establishment of a distinct statistical agency, medically manned, as part of a permanent health administration. The making of the Spanish health administration was secured during the first third of the twentieth century ${ }^{13}$ but, despite earlier attempts, it was only at the beginning of the 1930s that the agency came into being. The process by which this came about will be examined in this section.

Medical circles were sceptical but eager when the creation of the General Board for Statistics was announced. Their desire for more thorough, comprehensive data (including topics such as environmental conditions, familial heredity, or past therapeutic and clinical actions) fostered their demand for the involvement of doctors in the gathering of data. Francisco Méndez Alvaro, editor of the influential medical journal El Siglo Médico, had in 1856 been the first to realize the medical implications of cause-of-death statistics. ${ }^{14} \mathrm{He}$ considered it essential to examine many variables when the statistics of births and deaths were investigated, which in turn required, he believed, the presence of 'distinguished hygienists' in the central and provincial statistical agencies. Such a network, he further argued, would be best sponsored by the Royal Academy of Medicine of Madrid, the Royal Council of Health, and the provincial health boards. When new regulations placed a physician on the staff of the provincial statistical committees, El Siglo Médico demanded the unification of health and statistical administrations. The arbitrary appointment of doctors by provincial governors was considered an insufficient guarantee of successful collaboration. ${ }^{15}$ Years later, Méndez Alvaro described this period (1858-1867), as 'glorious for demography and statistics in Spain'. ${ }^{16}$

The most serious attempt to create a true register of demographic health statistics indeed occurred during this 'moderate decade', through the Royal Order of 10 May 1860. Pedro F. Monlau's support of the General Board for Statistics in 1862 added strength to the quest for more information on public health issues. But ten years later he emphasized that Spain still lacked real 'health statistics', having rather 'administrative statistics'. Secondarily useful for measuring morbidity, he found true health statistics desirable because they would 'always [be] produced by doctors' ${ }^{17}$ Since 1857, political leaders had understood and appreciated 
these objectives, and had pursued this 'delicate and important service', a 'most solid basis of public health', with the establishment of monthly statements of 'health and charity'. ${ }^{18}$

Royal Decrees of 30 April and 10 November 1865 ordered these monthly statements to be published in the Gaceta de Madrid and in the Boletines Oficiales in all provinces. However, 'administrative rashness and political instability' hindered progress from the outset. ${ }^{19}$ From our more distant perspective, it is evident that both the lack of technical expertise, which undermined all projects on health statistics, and the limited attention paid to statistical studies within medicine and university studies in general, contributed to the last in the gathering and exploitation of reliable records. ${ }^{20}$ Monlau's 1860s assessment seems the most accurate among contemporary observers: 'What is needed is an intelligent and directive center for health statistics, with personnel endowed with special understanding. ${ }^{, 21}$

Legislation regarding the Civil Registry (Registro Civil) was a breakthrough in the quest for statistics on health, but in no way addressed the underlying concerns of physicians. The most important public medical figures continually criticized the project for what they viewed as the relegation of doctors to secondary status. Méndez Alvaro claimed that the 1870 project restricted the 'liberty, independence and dignity' of physicians by having them work as 'free assistants of the Office of the Registry'. ${ }^{22} \mathrm{He}$ repeatedly complained of the lack of payment for registering births or certifying deaths when parents or other members of the family failed to pay the costs. Meanwhile Monlau $^{23}$ requested a medical section at the Registry. ${ }^{24}$

The obligation to publish collected data, along with the annual reviews and demographic statistics (imposed by the Royal Order of 7 February 1876), highlighted the same arguments used by hygienists twenty years earlier: both reported information on causes of death and the staff capable of making good use of the data were limited. The medical point of view was that death statistics needed to include data on place of birth, occupation, social status and financial situation, housing, educational level, illness preceding death, degree of contact with other sick individuals, and diagnosis of causal illness according to standard nosological frameworks, for each and every death. ${ }^{25}$ Méndez Alvaro proposed the creation of offices in all provinces and big towns, 'manned mainly by doctors who specialized in public health'. They would analyze demographic data and derive conclusions which could later help the government to make 'dispositions and regulations which are of use to public health, and facilitate good social organization' ${ }^{26}$

Méndez Alvaro's statements found a response in Barcelona. Two 
prominent physicians there, Ramón Coll y Pujol (1845-1915) and Luis Carreras y Aragó (1835-1907), persuaded the City Council to send weekly data on deaths to the German Imperial Office of Health, which could compare the information with other major European cities. They also counselled provincial governor Cástor Ibáñez Aldecoa to produce 'health statistics by deaths for all towns and villages of the province' in order to comply with the recommendations of the 1876 International Statistical Congress in Budapest. Data from the first year (1877-1878) were analyzed by the same Coll and Carreras in the Apuntes para la formación de la Demografía médica de la provincia de Barcelona y en especial de la capital, which were presented to the Academy of Medicine of Barcelona. ${ }^{27}$ From the Institute of Public Health of the City of Barcelona and until 1907, José Nin y Pullés (who died in 1892) and Luis Comenge Ferrer (1854-1916) collected and analyzed the data for the Barcelona municipal medical service. ${ }^{28}$ Data on Madrid, published after 1872 in the official state newspaper, La Gaceta de Madrid, in contrast were not analysed by medical experts. It was not until 1897 that the data were published in the form of a Boletín, in return for similar data sent from foreign capitals. ${ }^{29}$ Likewise, in 1897 a Boletín Mensual de Estadistica Sanitaria was issued by the Bilbao municipal government, as was the case with other cities.

Meanwhile Ibáñez Aldecoa was promoted to head the Department of Welfare and Public Health in 1879, and from this position he applied Barcelona's experience nationwide through a Royal Order of 28 June 1879 (Gaceta, 8 July 1879). Publication continued until $1884^{30}$ in the form of Boletines Mensuales de Estadística Demográfico Sanitaria de la Península e Islas Adyacentes. The main goal of this publication was to 'learn about the movement of the Spanish population and the best way to fight the diseases that decimate it'. It included data on births, including numbers of legitimate and illegitimate births, and on deaths by age and cause, for provinces and provincial capitals, and for municipalities with populations over $10,000 .{ }^{31}$

The terminology used in these various bulletins was the one adopted at the International Statistical Congress at Budapest in $1876 .{ }^{32}$ There is no doubt that the absence of a national statistical tradition helped to facilitate the adoption of international norms. The local source for these health statistics was the Office of the Civil Registry. Data taken from the Civil Registry were sent by local government to the provincial government, where a summary was made for the statistical service of the Public Health Department (Subdirección General de Sanidad) of the Department of Welfare and Public Health (Dirección General de Beneficencia y Sanidad). Instructions from the Registry Department were circulated on 30 April 1880 , to help in the addition of causes of death to the data gathered. The 
Department of Welfare and Public Health reiterated the instructions on 13 May $1880 .{ }^{33}$ Despite a nosological framework accompanying the instructions, the lack of systematic data for certain provinces and the absence of population counts by province limited the value of much of the data. ${ }^{34}$

Despite praising Aldecoa's scheme, physicians regarded the data gathered as inadequate, desiring instead a comprehensive view of all variables surrounding disease and death from a local, family, and personal perspective. ${ }^{35}$ They also demanded a salary for physicians, whether in private practice or in public service, as a recompense for their cooperation in completing the certificates. While problems of confidentiality did not arise, owing (or so it was said) to physicians' long familiarity (since 1837) with the filling in of the death certificates, the extra payment was justified by claiming the higher value of an ante-mortem diagnosis.

The secondary medical purpose of data collection had been to collect information on the major diseases in Spain. Here again the enterprise fell short of medical ideals and expectations, even though in January $1885^{36}$ a plan was made to improve the data with the addition of certain epidemic and endemic diseases, tallied by provincial district.

The cholera epidemic of that same year occasioned the suppression of the Boletin and it was not until three years later that it was replaced by the new Boletin de Sanidad, which appeared annually between 1888 and 1896. The new journal included data for Madrid and information on 'maritime' health (diseases among ships' crews and passengers, quarantines to be enforced, vaccination, and so on), but data on other cities and provinces were limited. Daily data were published for Madrid on deaths from certain infectious diseases (diphtheria, measles, smallpox) grouped by age, house, street, quarter, and district, and grouped daily, and monthly by main cause of death. ${ }^{37}$ Table 2 compares the classifications employed in the compilation of deaths prior to the adoption of Bertillon's classification. The medical influence is evident in the stress on the specificity of single diseases, and embodied the latest clinical knowledge.

The publication of statistics ceased in 1897 during Spain's colonial war with the United States. When the Department of Public Health and Welfare (suspended in 1892) reopened in 1899 as the Department of Public Health (Dirección general de Sanidad), one of the first proposals of its director, Carlos María Cortezo, was to resume the publication of the Boletin. The threat of plague in Portugal evoked the Department's renewed interest in cause-of-death data, as well as the feeling that the use of statistics aided 'the reform of regulations that protect public health' ${ }^{38}$ Local physicians were made directly responsible for collecting and forwarding the data to the provincial governments, which were in charge 


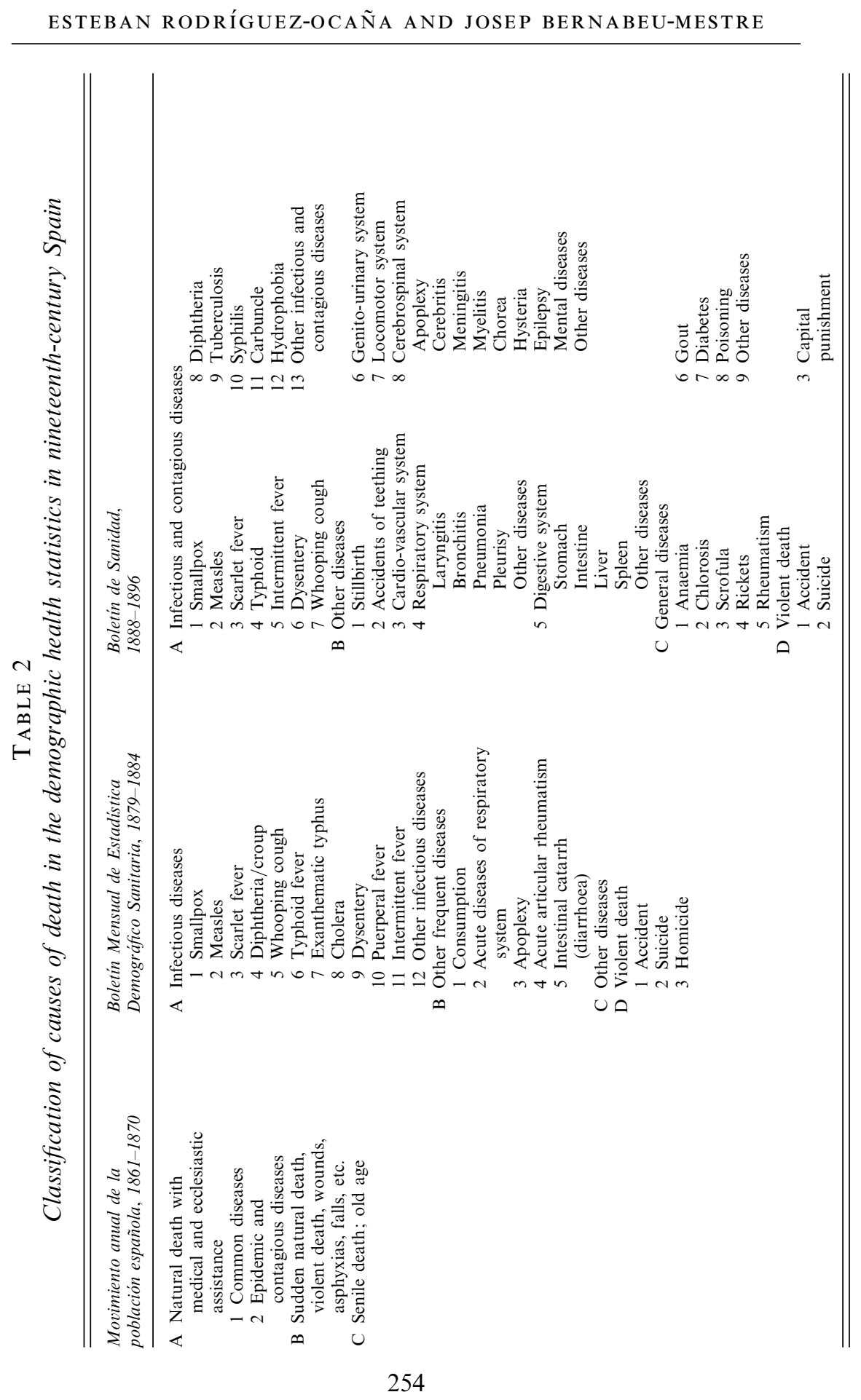


of sending them to the Department of Public Health in Madrid. However only one volume, concerning 1900, was published.

By April 1901, municipal governments were responsible for compiling monthly birth and death statements from the local office of the Civil Registry. These statements were to be sent to the Department of Public Health within the first ten days of the following month and were published in the Gaceta de Madrid. ${ }^{39}$ Monthly summaries were in fact published from May 1901 through December 1903 for all provincial capitals, and they followed Bertillon's abbreviated International Terminology (40 causal headings). Administrators were dissatisfied with the results, 'because many health officers failed to carry out such an indispensable duty'. ${ }^{40}$ Physicians, on the other hand, considered the contents insufficient because they wanted more data on hygiene and clinical therapies. ${ }^{41}$

In response to these divergent demands, the General Decree on Health of 1904 arranged for the systematic collection of morbidity statistics, obliging all physicians who worked in laboratories, asylums, and hospitals to send a monthly inventory of their patients, noting both diagnoses and the state of health of individuals released from such institutions. The data were to be collected by municipal health officers within the first ten days of the following month and sent to the provincial health officer through the subdelegates or district inspectors. The General Inspectorate for Border Health Control (Inspección de Sanidad Exterior), one of the two sections of the newly reconstituted Department of Public Health, whose remit was to deal with those health problems whose origins lay outside Spain, would receive 'whole data sets' (article no. 185) and would publish an abridged version in the Gaceta de Madrid. In addition, the Commission for Statistics of the Royal Council of Health would receive the data from the Inspectorate, and would analyze, comment on, and publish them semiannually in a new Boletín Demográfico Sanitario. That series began in July of 1905 with data from the first six months of $1904{ }^{42}$

The original plan called for the publication of statistics on births, deaths, marriages, fertility, morbidity, and other 'special statistics', with an abstract for each province. But the plan was never fulfilled. Marriage and fertility data for the first issue were taken from Movimiento de Población de España, año 1901, published by the Geographical and Statistical Institute. Cause-of-death data followed the norms set out in Bertillon's classification, and were grouped by province, provincial capital, age, and sex. 'Special statistics' included death by infectious or contagious disease, tuberculosis in provincial capitals (from 1901 to 1903), statistics on leprosy and mortality rates of children under four years of age. Due to difficulties in gathering morbidity data, none appeared in the first issue, and the editor expressed hope that they could be incorporated 
in the future if 'private practice doctors responded to the stimulus they received from health officials'. ${ }^{43}$

A new conservative government reorganized the health statistics service in July of 1909 (Royal Order of 2 July, signed by the minister La Cierva; Gaceta, 6 July) and ordered the monthly publication of data for provincial capitals and towns with populations over 10,000. Data would include general mortality (grouped by cause of death), mortality by specific infectious and contagious diseases, morbidity in hospitals and prominent charitable institutions, births, meteorological variables, and 'special' statistics. That such data were needed to monitor the health status of the population and to guide the action of health officers is clearly stated in the introductory words of the Royal Order of 2 July $1909 .{ }^{44}$ The challenge was to obtain a full set of complete statistics, as well as to publicize them in a timely fashion, thus making the Boletín de Estadistica Demográfico Sanitaria monthly once again. ${ }^{45}$

Incomplete data from 33 provinces necessitated modifications almost immediately. The Royal Order of 3 December 1909 (Gaceta, 22 December), signed by the liberal minister Alba, halted all data collection by municipal and district health officers, except in provincial capitals. In addition, statistics were only to be collected on infectious and contagious diseases, and birth and death data were to be taken from the Geographical and Statistical Institute. In exchange for these reductions, mandatory reporting was firmly imposed for a selected set of diagnoses.

The revised Boletín Mensual de Estadística Demográfico Sanitaria continued its publication from 1910 to 1920, grouping deaths by cause, sex of deceased, and three age groups (under 1 year, under 5 years, and over 5 years). ${ }^{46}$ Births were grouped by sex, legitimacy, and vitality (i.e., born alive, born dead, or dying during birth or within 24 hours after birth). Meteorological data, thermal and barometric oscillations, wind direction and rainfall, among other information, represented a seemingly outdated geo-climatic interpretation of epidemiology. Yet even in the 1930s Marcelino Pascua, the capable organizer of the Health Statistics Bureau from 1929 to 1931, and from 1931 to 1933 the first republican Head of the Department of Public Health, proposed maintaining such data collection in order to facilitate 'epidemiological studies'. ${ }^{47}$

The General Decree on Health (1904) clearly incorporated gathering statistics as one of the daily tasks of the health service, although a single regulation was not enough to repair the irregular operation of health inspection in Spain. In 1913, the General Inspector for Border Health Control (Sanidad Exterior; see above), Manuel Martín Salazar (1854-1936), declared that the results were unsatisfactory because of a lack of motivation among the doctors and municipal health officers in 
charge of data-gathering ${ }^{48}$ at the same time, the general unfamiliarity of Spanish physicians in dealing with statistical analysis was cited as one of the causes of the slow pace of health reforms. ${ }^{49}$ Accordingly, all statements from the government setting out the duties of physicians referred to their data-gathering obligations. The 1920 Regulations for the provincial Medical Officers (Inspectores provinciales de Sanidad) required them to ensure the notification of infectious diseases (Article 22), to guarantee that daily mortality reports were submitted (Article 23), and to draft and include annual accounts of 'provincial statistical data of importance to health' (Article 48).

On the other hand, the Local Health Regulation of 1925 stated that only morbidity (for registered diseases) and mortality data were to be used. Municipal Medical Officers (Inspectores municipales de Sanidad) were to obtain these mortality and cause-of-death data from the municipal authorities. These data, together with morbidity data submitted by physicians, would be directed to the Department of Public Health. The procedure is described in the following text, dated $1930:^{50}$

the provincial Health Inspection sends cards for notification to the municipal health inspectors, who are obliged to distribute them among doctors [and are required] to dispatch a monthly statement of all data gathered... within the first five days of the following month... The provincial health inspector is to add data for the provincial capital and charitable institutions and send it all to the Statistical Office of the Department of Public Health within the first fifteen days of the month.

The Royal Order of 26 November 1920 meanwhile discontinued the publication of the Boletin Mensual, but initiated the Anuario de la Dirección General de Sanidad, thus reducing the strain of a monthly journal. This Anuario gathered all subjects of interest to public health into two sections, one of technical, legislative, and administrative actions regarding public health and another dedicated to statistics. The publication of the Anuario was itself terminated in 1925, when a Royal Order of 25 November began the bimonthly Boletin Técnico de la Dirección General de Sanidad. Both journals lacked uniformity and regularity, and thus unfortunately cannot be considered effective sources of demographic health statistics.

The arrival of Francisco Murillo at the Department of Public Health (1923-1929) during the military dictatorship of Primo de Rivera did nothing to restore even the levels of data collection reached in the previous decade. The Boletín Técnico, for example, used only birth and death data from the former Geographical and Statistical Institute, now renamed the Bureau for Statistics. The data were arranged into 'Monthly summaries of births and deaths' (and accumulated into annual summaries), and were included in the section on statistics within the Boletin. ${ }^{51}$ This bulletin was 
later renamed Revista de Sanidad e Higiene Pública. The format of the monthly summaries was similar to the one in the previous Boletines Mensuales. ${ }^{52}$ The annual summaries included numbered sections giving details of mortality rates and comparisons between different provinces and provincial capitals. There were other unnumbered sections under the title 'Sections concerning natural movement of the Spanish population in the year...'. Information on causes of death was restricted to infectious diseases.

\section{The Health Statistics Bureau}

Once the Rockefeller Foundation, through its International Health Board (IHB), signed a cooperative agreement with the Spanish government in 1922, one of the first problems singled out by its delegate in Spain, Charles A. Bailey, was the absence of a regular Statistics Bureau (the term used by the Rockefeller Foundation's agents) within the Department of Public Health. Following the usual strategy of the International Health Board, he soon selected a capable man, Marcelino Pascua Martínez (1897-1977) to be trained in this field sponsored by the Foundation; in fact, this was his first proposal as such, in March 1925. ${ }^{53}$ However, the opening of the Health Statistics Bureau was not possible under Murillo's rule and apparently its creation had to wait until he was out of the government, that is, until the last months of 1929.

Through a resolution of March $1930^{54}$ past errors and reporting delays were criticized; 'with utmost urgency' compliance, especially in the notification of infectious and contagious diseases, was urged. A new weekly publication of a Boletin would contain data collected by physicians in provincial capitals and cities with populations over 20,000. These goals were accomplished quickly, on 1 June for the largest cities and on 5 October for the remainder. ${ }^{55}$ The republican governments kept the resolution in place. The capable crusader Marcelino Pascua became Head of the Department of Public Health (Director general de Sanidad) (1931-1933), and from this position introduced a death certificate that allowed a distinction between immediate and underlying causes of death, a model already in use in various other countries ${ }^{56}$ Use of these forms became compulsory on 1 January 1932 but, as late as 1936, inevitable 'deficiencies and delays' in reporting persisted. ${ }^{57}$

The weekly Boletin also included data from the Central Malaria Commission (Comisión central antipalúdica) on malaria and other parasitic diseases. Mortality by age and cause of death (according to the abbreviated international classification of 1930) was available only for the city of Madrid. During the republican regime, the Health Service maintained the monthly and annual summaries of data for each province 
and provincial capital, provided by the Statistical Institute. Data appeared in the Revista de Sanidad e Higiene Pública, but due to delays in the Institute's publication of demographic statistics, the Department of Public Health began publication of a Resumen de Natalidad y Mortalidad de España en el año ..., a yearly abstract of data from the previous year. ${ }^{58}$

Pascua, in his paper 'Organización del servicio de estadísticas sanitarias y su utilización', given at the First National Health Congress (1934), described current practices and offered an ambitious theory on the interrelation between public health administration and the creation of statistics. He denounced the apathetic conduct of some of the local and provincial health officers, and maintained that data should be studied comparatively in order to improve local public health. He also insisted that statistics should guide the introduction of effective, specific policies.

When the last pre-war Order on public health was written, on 15 February 1936, statistics were regarded as an important part of a modern epidemiological framework. Epidemiologists from the Provincial Institutes for Public Health (Institutos provinciales de Sanidad) were to carry out 'meticulous studies' based on the data provided. It was their responsibility to write the accompanying reports, as well as to compare the monthly totals for provincial capitals tallied from the weekly reports with those published in the Revista de Sanidad e Higiene Pública. Between December 1935 and January 1936, there was an attempt to translate into practice Pascua's ambitious ideas, such as the compilation of morbidity data, assigning the tasks to the Provincial Institutes for Public Health. But the orders were soon suspended due to their 'limited intrinsic value' and the already heavy workload on the public health system. ${ }^{59}$

Weekly summaries of demographic health data resumed after the Civil War. The Health Statistic Bureau of the Department of Public Health (in the Home Ministry), edited an issue of Datos Relativos a la Semana que Terminó con el Sábado... within two weeks of the Saturday ending any given week. The data and format were the same as those of the Boletines Semanales de Estadisticas Sanitarias published during the Republic. ${ }^{60}$

\section{CONCLUSIONS}

Although statistics are considered one of the main pillars of public health systems, the creation of Spanish demographic and health statistics was a slow and contradictory process. The slowness was due to the lack of stable social policy during the period from 1841 to 1936. Statistical agencies were mostly founded under liberal governments, such as the first Republic, which implemented the Law of Civil Registration. Furthermore, health administration did not become a public service directed towards the 
day-to-day well-being of the population until the twentieth century. We believe that delays in establishing these essential government services were a consequence of the confrontational style prevailing in Spanish society.

There were important differences between proposals originating with physicians and those of the bureaucrats. Physicians tried to advance a 'maximum programme' in which most of the circumstances surrounding people's lives would be recorded, arguing that otherwise the data would be unintelligible from a public health point of view. While this might be viewed as an attempt by doctors to improve their social status and assert their superiority over mere statisticians, the effect was a persistent effort to achieve a health-oriented approach to population statistics.

Decisions of administrative agencies were much more cautious, and those that seemed too rash (such as those of December 1909 and January 1936) were quickly amended. The lack of personnel and specialized instruction were the main reason for this cautious approach. Similar deficiencies were felt in the area of health, where conditions only started to improve with help from the Rockefeller Foundation in the late 1920s. Weakness in the primary stage of the health administration - municipal health officers were established in all towns, on paper, only in $1904-$ inhibited the construction of a solid nationwide health-statistical service. As a result, the only achievement of the 'maximum programme' of nineteenth-century hygienists was the weekly notification of reportable diseases. The failure of the physicians' approach enhanced both the credibility and the importance of the Spanish Statistical Institute.

\section{ENDNOTES}

1 B. Nogueras and M. N. Pombo, 'Estadística y censos en la España del siglo XIX: reseña de los nuevos tiempos', in D. Reher, B. Nogueras, and M. N. Pombo, España a la luz del censo de 1887 (Madrid, 1993), 10. And see J. Fontana, 'Prólogo', in A. Carreras ed., Estadisticas históricas de España, siglos XIX y XX (Madrid 1989), 7.

2 J. M. López Piñero, Los orígenes en España de los estudios sobre Salud Pública (Madrid, 1989), 17-21.

3 The best local study thus far on the public health and burials is E. Santamaría and M. L. Dabrio, 'La Policía sanitaria mortuoria y su proceso de secularización en la Sevilla de la Illustración (1750-1800)', Medicina e Historia 50 (1993).

4 Nogueras and Pombo, 'Estadística', 9.

5 Instrucción para el gobierno político de las provincias (23 June 1813), made law 3 February 1823; the Royal Decree of 23 July 1835 (which became law on 19 January and 14 May 1836), and the Circular of 1 December 1837. These and other early pieces of legislation are summarized in 'Recopilación de las leyes, decretos, reales órdenes y circulares que se refieren al moviemento natural de la población', in Memoria sobre el movimiento de la población de España en los años 1858, 1859, 1860 y 1861 (Madrid, 1863), xv and ff.

6 Circular of 1 December 1837; see 'Recopilación de las leyes', xvii. 
7 Royal Order 17 June 1863, reproduced in F. Abella, Manual administrativo de sanidad terrestre y maritima, 2nd edn (Madrid, 1879). It assigned the property of cemeteries exclusively to city councils, so that they came under municipal responsibility.

8 R. Revenga, 'Organización de la estadística en España. Apéndice 1', in J. Bertillon, Curso elemental de estadistica administrativa (Madrid, 1907), 594-616.

9 'Exposición', in Memoria (1863), viii-ix, citing problems such as 'the lack of administrative means [and] qualified personnel'; 'the difficulty in having the clergy under temporary subordination and participating in joint projects'; and difficulties in overcoming popular 'apathy and indifference'.

10 'Until rigorous inscription is part of our popular tradition, statistical studies will be insufficient... because of the withholding of facts' ('Prólogo', in Movimiento de la Población de España en el decenio de 1861 a 1870 (Madrid, 1877), vi). The 'Recopilación de las leyes', xxiv, says: 'Since villages usually hide the truth, the central authorities should convince the municipal authorities that data given about births, marriages and deaths do not change the volume of taxable income; they allow the study of how the Spanish population reproduces, grows, develops and ends; and these social facts should be studied in depth for the Government to determine which measures to introduce for the benefit of humanity.' (This and all subsequent translations are those of the authors of this article.)

11 Movimiento de la Población de España (Madrid, 1895), 11 and 25.

12 R. Maurell García, 'La mortalidad en España en 1900', Gaceta Médica de Granada 20 (1902), 505-12; 'Memoria', Boletín Demográfico Sanitario (1905), ix; M. Pascua, 'Mortalidad española en el siglo XIX', Revista de Sanidad e Higiene Pública, 9/1 (1934), 577-79.

13 E. Rodríguez Ocaña, 'The making of the Spanish Health Administration during the first third of the twentieth century', Quaderni Internazionale di Storia della Medicina e la Sanità (Siena) 3 (1994), 49-65.

14 F. Méndez Alvaro, 'Algunas consideraciones sobre estadística', El Siglo Médico 3 (1856), 593-4, and 'Estadística del cólera morbo', El Siglo Médico 4 (1857), 321-2. Francisco Méndez Alvaro and Pedro Felipe Monlau were the most prolific publicists when it came to public health during the middle third of the nineteenth century. See M. Granjel, Pedro Felipe Monlau y la higiene española del siglo XIX (Malaga, 1983); and J. L. Fresquet Febrer, Francisco Méndez Alvaro (1806-1883) y las ideas sanitarias del liberalismo moderado (Madrid, 1990).

15 B.R., 'Importancia de la higiene y consequencias de su olvido. Comisiones permanentes de estadística', El Siglo Médico 4 (1857), 161-2.

16 F. Méndez Alvaro, 'El Registro Civil en España', El Siglo Médico 24 (1877), 131-4; 162-7; 194-9, and 242-7, esp. p. 196.

17 See P. F. Monlau, Elementos de higiene pública, 2nd edn (Madrid, 1862), 130: 'at last, we are on the right track and we should continue like that'. And see the third edition (Madrid, 1871), 736-8, for the quoted passage. See also the plan proposed by José Garófalo ('Breves indicaciones sobre un plan general de estadística médica', El Siglo Médico 8 (1861), 163-5) as proof of the thoroughness desired by doctors worried about the difficulties of compiling useful statistics. He proposed the collection of data for each individual sick person including, among other aspects, town of origin, therapy prescribed, and outcome.

18 Decrees and Circulars of 23 and 26 February, 22 May, and 2 and 3 June 1857.

19 F. Méndez Alvaro, 'Estadística sanitaria', El Siglo Médico 12 (1865), 333-4. 'Advertencia', in Boletín Mensual de Estadística Demográfico-sanitaria de la Penísula e Islas Adyacentes. Segundo semestre de 1879 (Madrid, 1880), unpaginated. 
20 E. Rodríguez Ocaña, 'Presencia de la estadística en los manuales españoles de higiene pública', in M. Valera, M. D. Egea, and M. D. Blázquez eds., Libro de Actas. VIII Congreso Nacional de Historia de la Medicina, Murcia-Cartagena, diciembre 1986 (Murcia, 1988), 431-40.

21 Monlau, Elementos (1871), 737. Almost the same words were used by the International Health Board's delegate in Spain, Charles A. Bailey, commenting on the same problem in 1925.

22 F. Méndez Alvaro, 'El Registro Civil', El Siglo Médico 17 (1870), 405-9.

23 Monlau, Elementos (1871), 305.

24 From November 1872 in Madrid and May 1887 in Barcelona, a service for the examination of corpses was established, staffed by medical examiners. This was replaced in 1907 by a corps of physicians attached to the service, and extended to all cities with populations over 50,000 by Royal Orders of 4 August and 29 September 1918. In July 1925, all provincial capitals and cities with populations over 40,000 came under these directives. During the Republic, the Registry was suspended, but Franco's regime reopened it on 27 July 1939, appointing all staff directly from the Ministry of Justice.

25 Méndez Alvaro, 'El Registro Civil', 133-4.

26 Méndez Alvaro, 'El Registro Civil'. Other people were aware that these compilations were of little meaning to public health, but their proposals departed from the more ambitious medical claims of Méndez, simply suggesting the use of physicians to tabulate the data. Such was the case with Ruiz Jiménez, 'Observaciones (al censo de Madrid y estadística demográfica)', El Siglo Médico 26 (1879), 265-6.

27 Cited in R. Rodríguez Méndez, 'Estadística demográfica de Barcelona', Gaceta Médica Catalana 15 (1892), 481-5. On the founding of the Catalan organization, see 'Estadística sanitaria de Barcelona y su provincia', Revista de Ciencias Médicas 5 (1879), 186-8.

28 E. Rodríguez Ocaña, 'La labor estadística de Luis Comenge (1854-1916) en el Instituto de Higiene Urbana de Barcelona', Dynamis 5-6 (1985-1886), 279-306.

29 Decree of Mayor's office, 26 November 1896, printed on 26 February 1897. Archivo histórico de la Villa (Madrid), 17-388-25. The year 1899 saw the first issue of the Anuario Estadístico Demográfico. Publication continued with data for 1900 as Estadística Demográfica del Ayuntamiento de Madrid.

30 The last issue of the Boletin was actually published in 1887 and provided data on the cholera epidemic in 1885 .

31 In age groups of less than 1 year, between 1 and 5 , between 5 and 10, between 10 and 20 , between 20 and 40, between 40 and 60 , and older than 60 .

32 'Although it should be revised in the future, we think it will always be convenient to remain close to the terminology used in other countries, in order to facilitate comparative studies' ('Advertencia', in Boletín Mensual de Estadística Demográficosanitaria de la Peninsula e Islas Adyacentes. Segundo semestre de 1879 (Madrid, 1880), unpaginated).

33 According to the introduction to the Royal Order of 8 October 1880 (Gaceta, 10 October), which set out the regulations which should govern the demographic health statistics service. However, we have no information about the actual collection processes.

34 R. Rodríguez Méndez, 'Revista de Higiene', Revista de Medicina y Cirugía 6 (1880), 273-4. With this in mind, data published in the Boletines from 1879 to 1884 are analysed in the research project DGICYT PM89-023: E. Balaguer Perigüell, et al. 'Análisis demográfico-sanitario: estudio de la evolución temporal y distribución geográfica de 
estructura de la mortalidad por causas de defunción', La transición epidemiológica en España de 1879 a 1919 (University of Alacant, 1993).

35 R. Vazalde, 'Un intento laudable. Estadística sanitaria', El Siglo Médico 26 (1879), 466-9.

36 Royal Order of 5 January 1885 (Gaceta, 23 January); 'Legislación de fecha atrasada. Sanidad terrestre', in Boletin de Sanidad, 1890, 158-60.

37 Grouped by ages up to 5 months, 5 months to 3 years, between 3 and 6 , between 6 and 13, between 13 and 20, between 20 and 25, between 25 and 40 , between 40 and 60 , between 60 and 80 , and older than 80

38 Circular of 12 December 1899 (Gaceta, 16 December).

39 'Memoria', in Boletín Demográfico Sanitario, 1905, ix.

40 Ibid., $\mathrm{x}$.

41 C. Calleja, 'Perfeccionamiento de la estadística médica', El Siglo Médico 48 (1901), 244-6.

42 'Inspección General de Sanidad Exterior', Boletín Demográfico Sanitario, 1904, ler semestre, 1905. A Royal Order of 20 June 1904 ordered its publication and permitted the publication of subsequent ones.

43 Ibid., xii.

44 '...effective statistics that serve as a base when dealing with the country's public health They should also serve as a faithful indicator of the measures taken by the authorities, to guide the hygienist and the governor when studying mortality ... to discover all accidental or chronic ailments that corrode the life of a people, and to provide essential elements of judgement for the application of fruitful reforms'.

45 This publication also quantified the activities of laboratories, the public health provincial institutes, and harbour health stations, in addition to gathering diagnoses from hospitals, asylums, and other institutions.

46 Deaths in charitable institutions were only divided into two age groups: under age 5 and over age 5 .

47 M. Pascua Martínez, 'Organización del Departamento de Estadísticas sanitarias y su utilización', in L. Nájera Angulo ed., Actas del Primer Congreso Nacional de Sanidad (Madrid, 1934), Vol. III, 337-48.

48 'Municipal health officers, who are at the same time town physicians, are not paid for gathering and forwarding data on infectious diseases, and thus forget their obligation; but the existing structure of the statistical service, established by the present Decree of Health, does not provide legal means by which to enforce compliance' (M. Martín Salazar, La Sanidad en España (Madrid, 1913), 61).

49 Angel Fernández Caro, 'Introducción', to Francisco G. Membrillera, El problema sanitario de España (Barcelona, 1921), iii.

50 G. Banqueiro Gil, Introducción a la metodología estadistica aplicada a las cuestiones sanitarias (Madrid, 1930), 120-1.

51 Before mid-year there was to be an annual summary of the previous data as well. Thus, in May 1927 the annual summary for 1926 was published (Boletin Técnico de la Dirección General de Sanidad 2, 319-55); the one for 1927 was published in Volume 3, pp. 203-39; the one for 1928 in Volume 4, pp. 222-59; and the one for 1930 in Volume 5, pp. $138-75$.

52 Particular attention was paid to typhoid fever, smallpox, measles, scarlet fever, whooping cough, diphtheria and croup, influenza, pulmonary tuberculosis, cancer and other malignancies, and puerperal septicaemia.

53 Rockefeller Archive Center, RF, 5, 1.2, 238, 3060, Bailey to Russell (letter), 9 March 1925. On the relationship with the Rockefeller Foundation see E. Rodríguez Ocaña, 
J. Bernabeu Mestre, and J. L. Barona, 'La Fundación Rockefeller y España, 1914 1936. Un acuerdo para la modernización científica y sanitaria', in VI Congreso de la Sociedad Española de Historia de las Ciencias y de las Técnicas. Segovia, septiembre 1996 (publication forthcoming).

54 Royal Order of 27 March 1930 (Gaceta, 29 March), 1971-2.

55 In the First National Health Congress (1934), a paper given by Pascua (cited in n. 47 above), the head of the Health Statistics Bureau of the Department of Public Health boasted that the Boletin Semanal had been published 'without interruption since 7 June 1930'.

56 Circular of 2 June 1931 (Gaceta, 7 June).

57 Circular of 3 May 1936 (Gaceta, 6 May). The last legal text on public health policy before the Civil War, Order of 15 February 1936 (Gaceta, 18 February, ratified 20 February), complained about the 'notorious and highly confirmed neglect' of basic health-care professionals in the process of gathering statistical data. In the supplement to Estadisticas Sanitarias no. 241 (1934), Pascua wrote: 'the obvious irregularities present in data from provincial Medical Officers used in this work (on typhoid fever morbidity) demand caution from those interested in this subject'. Quoted in A. Salvat Navarro, Tratado de Higiene (Barcelona, 1935), Vol. III, 783.

58 For example, the ones for 1933 (1934; Madrid, 41 pages) and for 1934 (1935; Madrid, 41 pages).

59 Order of 16 January 1936 (Gaceta, 21 January).

60 Mandatory declarations, grouped by cities with populations greater than 20,000 and by provinces, included data for births (live or dead), total deaths, deaths of children under 1 year of age, and the number of cases and deaths from 'EDO' - diseases requiring separate reporting. Cumulative data for the remaining towns and villages, grouped by province, were provided, as well as a distribution of deaths by cause (according to the abbreviated international classification of 1941) for the city of Madrid. 